\title{
ARHGEF10 Gene
}

National Cancer Institute

\section{Source}

National Cancer Institute. ARHGEF10 Gene. NCI Thesaurus. Code C147565.

This gene plays a role in both GT Pase activation and nerve myelination. 